\title{
EMPLOYEE CAPITALISM OR CORPORATE SOCIALISM? \\ BROAD-BASED EMPLOYEE STOCK OWNERSHIP
}

\author{
by \\ E. Han Kim * \\ University of Michigan \\ and \\ Paige Ouimet * \\ University of North Carolina
}

CES 09-44 December, 2009

The research program of the Center for Economic Studies (CES) produces a wide range of economic analyses to improve the statistical programs of the U.S. Census Bureau. Many of these analyses take the form of CES research papers. The papers have not undergone the review accorded Census Bureau publications and no endorsement should be inferred. Any opinions and conclusions expressed herein are those of the author(s) and do not necessarily represent the views of the U.S. Census Bureau. All results have been reviewed to ensure that no confidential information is disclosed. Republication in whole or part must be cleared with the authors.

To obtain information about the series, see www.ces.census.gov or contact Cheryl Grim, Editor, Discussion Papers, U.S. Census Bureau, Center for Economic Studies 2K130B, 4600 Silver Hill Road, Washington, DC 20233, Cheryl.Ann.Grim@census.gov. 


\begin{abstract}
How employee share ownership plans (ESOPs) affect employee compensation and shareholder value depends on the size. Small ESOPs, defined as those controlling less than 5\% of outstanding shares, benefit both workers and shareholders, implying positive productivity gains. However, the effects of large ESOPs on worker compensation and shareholder value are more or less neutral, suggesting little productivity gains. These differential effects appear to be due to two non-value-creating motives specific to large ESOPS: (1) To form management-worker alliances ala Pagano and Volpin (2005), wherein management bribes workers to garner worker support in thwarting hostile takeover threats and (2) To substitute wages with ESOP shares by cash constrained firms. Worker compensation increases when firms under takeover threats adopt large ESOPs, but only if the firm operates in a non-competitive industry. The effects on firm valuation also depend on the strength of product market competition: When the competition is strong (weak), most of the productivity gains accrue to employees (shareholders). Competitive industry also implies greater job mobility within the industry, enabling workers to take a greater portion of productivity gains.
\end{abstract}

JEL classification: G32, M52, J54, J33

Keywords: ESOPs, Employee Incentives, Worker Wages and Compensation, Product Market Competition

* We are grateful for helpful comments/suggestions by Sreedhar Bharath, Joseph Blasi, Amy Dittmar, Charles Hadlock, Diana Knyazeva, Doug Kruse, Francine Lafontaine, Margaret Levenstein, Randall Morck, Clemens Sialm, Jagadeesh Sivadasan, seminar participants at INSEAD, North Carolina State University, University of Hawaii, University of Michigan, University of Oxford, the US Bureau of Census and Washington University at St. Louis, and participants of the Conference on Financial Economics and Accounting, Madrid conference on Understanding Corporate Governance, the Census Research Data Center Annual Conference, and the International Conference on Human Resource Management in Banking Industry. We acknowledge financial support from Mitsui Life Financial Research Center. The research was conducted while the authors were Special Sworn Status researchers of the U.S. Census Bureau at the University of Michigan and Triangle Census Research Data Center. We thank Clint Carter and Bert Grider for their diligent assistance with the data and clearance requests. Any opinions and conclusions expressed herein are those of the author(s) and do not necessarily represent the views of the U.S. Census Bureau. All results have been reviewed to ensure that no confidential information is disclosed. 
Broad-based employee share ownership (ESO) is an important economic phenomenon. According to the 2006 General Social Survey, ${ }^{4} 18 \%$ of U.S. workers surveyed reported owning company stocks of their employer (Kruse, Blasi and Park 2009). The two most common types of ESO plans are Employee Stock Ownership Plans (ESOPs) and 401-K plans with employer stocks. According to the National Center for Employee Ownership, in 2007, nearly 14 million employees participated in 9,650 ESOPs, with combined assets over $\$ 925$ billion at public and private firms. The corresponding numbers for ESO through 401-K plans are seven million participants with $\$ 275$ billion in assets. Both of these plans show an increasing long-term trend; the NCEO estimates the number of participants in ESOPs was one-quarter million in 1975, five million in 1990, and about 14 million in 2007. ESO through 401-Ks has also become increasingly popular since the 1990s.

Previous studies have documented worker productivity increases following adoption of ESO or employee profit sharing plans (Jones and Kato, 1995; FitzRoy and Kraft, 1987; and Beatty, 1995). The finance literature also shows positive stock price reactions to the announcement of ESOP adoptions that are not implemented under takeover pressure (Gordon and Pound, 1990; Chang and Mayers, 1992; Chaplinsky and Niehaus, 1994; and Beatty, 1995). However, there is little evidence on how ESO plans affect employee compensation.

The effect on employee compensation is an important issue. It has an obvious employee welfare implication. Moreover, any change in employee compensation has implications for firm valuation and shareholder value. A typical ESO bestows not only

\footnotetext{
${ }^{4}$ The General Social Survey is conducted by the National Opinion Research Center of the University of Chicago.
} 
cash flow rights, but also voting or other forms of control rights to employees. As the size of ESO increases, greater cash flow rights may lead to greater productivity gains through improved team effects and collective employee behavior (Kruse, Freeman and Blasi, 2009). However, employee control rights will also increase, which may affect corporate governance and employee compensation. It is not clear how greater cash flow and control rights jointly affect productivity gains and the division of the gains between employees and shareholders. This paper conducts an empirical investigation of how ESOPs affect employee compensation and shareholder value, and by implication, the size of the economic pie.

The data on employee compensation is obtained from a unique establishmentlevel database maintained by the Center for Economic Studies at the U.S. Bureau of Census. An establishment is any facility with a separate physical address, such a plant, a retail store, a restaurant, and so on. The regression estimates on wages control for establishment fixed effects, year fixed effects, state-year mean wages, industry-year mean wages, establishment age, and other firm-level variables. Panel regressions are estimated using all treatment firms and a control group matched by size, average firm wage, and trends in wage changes prior to the ESOP initiation.

We find that that firms with small ESOPs, defined as those controlling less than 5\% of shares outstanding, increase both employee wages and shareholder value. We infer from this evidence that employee capitalism works in the case of small ESOPs; they increase worker productivity and the gains are shared by employees and shareholders. In contrast, large ESOPs with employee share ownership greater than 5\% seem to have 
more or less neutral effects on both employee compensation and shareholder value, implying little productivity gains associated with large scale employee ownership.

To explain why the size of ESOPs makes such a difference, we investigate two non-mutually exclusive hypotheses specific to large ESOPs: (1) Large employee control rights permeate corporate socialism, negating potential productivity gains and (2) Some large ESOPs are used as a means to substitute cash wages with stock by cash-constrained firms.

A specific form of corporate socialism that is particularly relevant to large ESOPS is management-worker alliance in which management intentionally bestows substantial control rights to employees by implementing large scale ESOPs. This alliance hypothesis is based on the Pagano and Volpin (2005) model in which managers concerned with hostile takeover threats bribe workers with above-market wages in return for their cooperation in fending off hostile bids. Large ESOPs can be effective in protecting incumbent management against hostile takeover threats. Chaplinsky and Niehaus (1994) document the probability of successful takeover dropping by nearly $50 \%$ when the target firm has an ESOP in comparison to firms without ESOPs. We hypothesize that if ESOPs are adopted to form management-worker alliance, workers will be rewarded with higher compensation.

To test the alliance hypothesis, we focus on firms operating in concentrated industries. Management-worker alliance represents employee entrenchment; as such, its sustainability requires corporate slack. When firms operate in a highly competitive industry, survival requires efficiency, leaving little slack. Such firms are forced to practice good governance, which is less compatible with employee entrenchment. 
Consistent with this conjecture, Guadalupe and Wulf (2007) provide evidence that product market competition improves governance; and Giroud and Mueller (2009) demonstrate that product market competition serves as an effective external governance mechanism.

We find that worker wages, excluding the value of ESOP shares granted, increase more following large ESOPs implemented under takeover pressure. This applies only to firms operating in concentrated industries. For those operating in competitive industries, wages decline more following similar type of ESOP initiations. These firms have little slack due to competition and, hence, may have to undertake restructuring measures including wage cuts, once they are put into play for a takeover contest.

Large ESOPs as a means to form management-worker alliance are especially plausible for companies subject to Business Combination Statutes (BCS), which state that if a block of investors, unaffiliated with management, vote against a tender offer, the bidder must wait three to five years before pursuing the takeover. Because courts have established ESOPs as "outside" investors, BCS make large ESOPs an effective antitakeover device. We find that wage increases at firms in concentrated industries with large ESOPs following BCS passage, rendering further support for our hypothesis that some large ESOPs in concentrated industries reflect worker-management alliances. We find no such evidence at firms with small ESOPs subject to BCS.

To examine whether ESOPs established by cash constrained firms have differential effects, we follow Hadlock and Pierce (2009) and identify cash constrained firms as young firms with small assets. We find that large ESOPs initiated by cash constrained firms are associated with $12 \%$ lower wages, relative to large ESOPs initiated 
by non-cash constrained firms. Much of the marginal negative wage effects of large ESOPs observed for the total sample is driven by firms that appear to be cash-constrained. Our estimation for the net marginal effect of large ESOPs implemented by non-cashconstrained firms is $-1.7 \%$, which can be easily covered by the value of ESOP shares granted in large ESOPs. (Our estimation of worker wages does not include the value of ESOP shares.) Thus, we conclude that large ESOPs established by non-cash-constrained firms have no negative effect on total employee compensation.

Finally, we examine how the relation between firm valuation and the size of ESOPs depends on the strength of product market competition. We find that the small ESOPs' positive effect on shareholder value is especially strong in concentrated industries; firm value increases by $26 \%$ relative to the sample mean. When product market competition is strong, the positive valuation impact is much smaller at $8 \%$.

When these valuation results are considered together with the wage results, an interesting pattern emerges. In concentrated industries, most of the productivity gains arising from employee ownership seem to accrue to shareholders, whereas in competitive industries the gains accrue to mostly to workers. We interpret this result as product market competition also affecting labor market competition. Workers with industryspecific human capital will have relatively few alternative employers when their employer operates in a concentrated industry; thus, they are less likely to quit if dissatisfied with their wages. This will limit their ability to share in the gains associated with ESOP-related productivity increases, allowing the shareholders to enjoy most of the gains. Conversely, strong competition for labor allows workers to capture the lion's share 
of their productivity gains. Our measure of industry concentration is based on the number of employees; as such, it also measures job mobility within an industry.

This paper contributes to the literature on several fronts. First, we find that, on average, wages increase following the adoption of small ESOPs, as does shareholder value. The wage result is consistent with efficiency wage arguments that higher compensation levels can pay for themselves through higher productivity. We also find interesting cross-sectional patterns in who benefits from ESO. In concentrated industries with limited mobility for employees, shareholders capture the lion's share of the gains, whereas in competitive industries, employees capture the lion's share of the gains.

We also find that some ESO plans are used by cash-constrained firms to substitute cash compensation with stocks. The potential for firms to alleviate cash constraints through ESO has been debated by Core and Guay (2001) and Oyer and Schaefer (2005), which find inconsistent results regarding whether financially constrained firms are more likely to establish broad-based stock ownership plans.

Finally, we document evidence of some large ESOPS serving as a means to worker-management alliance. Earlier studies find negative stock price reaction to the announcement of ESOPs by firms under takeover pressure, suggesting that some ESOPs act as anti-takeover device (Gordon and Pound, 1990; and Chang and Mayers, 1992). Our finding illustrates that the anti-takeover device requires management-worker alliance, from which employees reap a permanent increase in compensation at the expense of shareholder value.

The rest of the paper is organized as follows. Section I briefly surveys the literature on costs and benefits of employee share ownership and identifies a number of 
potential motives for establishing ESOPs. Section II describes the data. Empirical results are presented in Section III. Section IV concludes.

\section{Effects on employees and shareholders}

In this section we survey the relevant literature and identify three non-mutually exclusive motives to establish ESOPs: (1) an attempt to improve incentives and team efforts to enhance worker productivity, (2) management-worker alliance to thwart hostile takeover threats, and (3) substituting stocks for cash wages by cash constrained firms. First we summarize the literature on worker productivity through improved incentive and team effects, followed by discussions on the other potential effects.

\section{A. Productivity gains}

The most frequently stated objective of ESO is to increase firm value by improving employee incentives. Shareholders typically do not monitor non-managerial employees; instead, they delegate the monitoring to management, agents themselves vulnerable to their own incentive problems. As a supplement to delegated monitoring and to better align employee incentives with shareholder values, firms may encourage ESO as an incentive device. However, individual workers may feel they have little impact on stock price, raising doubt on the ability of ESO to alter individual behavior in tasks requiring additional individual effort or sacrifice.

Collectively, however, important benefits may arise if ESO provides a proper group-based incentive. Kandel and Lazear (1992) argue that free-rider problems can be mitigated by orientation and indoctrination of new employees about workplace norms, which creates a work environment where peer pressure enforces the group-based 
incentive. FitzRoy and Kraft (1987), Blasi, Conte, and Kruse (1996) and Kruse, Freeman and Blasi (2009) also argue that group-based incentive schemes such as ESO encourage co-monitoring, reducing costly monitoring by managers. Jones and Kato (1995) argue that ESOPs induce employees to develop a sense of identity and loyalty to their company; participate more actively in productivity-enhancing activities, such as quality-control circles; and increase the quality of decision making. These arguments are consistent with the claims often made by firms initiating ESOPs that ESO improves team work by fostering a culture of employee involvement.

ESO also may help prevent value loss arising from labor disputes. Cramton, Mehran, and Tracy (2007) develop a model in which share ownership by unionized workers creates incentives for unions to refrain from costly strikes.

These theoretical arguments on productivity are supported by Jones and Kato (1995) who document that an ESOP adoption in Japan leads to a 4-5\% increase in productivity, starting about three years after the adoption. This is remarkable because the typical Japanese ESOP is allocated $1 \%$ or less of outstanding shares, demonstrating that even very small ESOPs generate substantial productivity gains. Japanese ESOPs do not provide tax benefits and most shares are allocated to non-executive employees. ${ }^{5}$ In addition, FitzRoy and Kraft (1987) find that profit sharing and workers' capital ownership have positive effects on factor productivity for a sample of metal working firms in West Germany. Although there are no comparable studies on worker productivity for U.S. firms, Beatty (1995) finds an increase in sales in the two years after the adoption of an ESOP.

\footnotetext{
${ }^{5}$ In an earlier study (1993), Jones and Kato report that $91 \%$ of all firms listed on Japanese stock markets had an ESOP in 1989.
} 


\section{B. Employee compensation}

How are these productivity gains shared between employees and shareholders? Akerlof and Yellen (1990) argue that workers will demand a "fair" wage. One definition of a fair wage could include a share of firm profits. As profits increase, workers will demand higher wages (a "fair" share of the surplus) and be more inclined to shirk or even quit if wages fall short. Empirical evidence consistent with rent-sharing models include Hildreth and Oswald (1997) who find that wages increase following shocks to firm-level productivity. Thus, we hypothesize that employees will capture a share of productivity gains.

A typical ESO bestows not only cash flow rights, but also voting or other forms of control rights to employees. When the size of ESO is large, workers obtain important influence on the firm's governance, which in turn may affect wages. In the context of managerial pursuit of a "quiet life" in Bertrand and Mullainathan (1999, 2003), substantial employee control rights may exacerbate the managerial tendency to acquiesce to worker demands for higher wages. Large employee ownership may also be a result of worker-management collusion as theorized by Pagano and Volpin (2005). Powerful employees may induce management to shift its allegiance to workers, leading to managerial actions harmful to shareholder value, such as value destroying asset sales documented by Atanassov and Kim (2007). Thus, we predict lower productivity gains but higher employee compensation when the size of ESO is larger. ${ }^{6}$

\footnotetext{
${ }^{6}$ The quiet life hypothesis, while predicting higher employee compensation, does not necessarily imply lower productivity gains.
} 
In an extreme, employees with sufficient control rights may even extract unearned compensations and benefits at the expense of other stakeholders, increasing the firm's marginal costs and eroding growth opportunities. Such firms will invest less, suffer poor performance, and be valued lower. Faleye, Mehrotra, and Morck (2006) observe such phenomena for firms with large ESO. However, they also raise the possibility that poorly managed and badly performing firms may establish large ESO plans to share their misfortune with employees.

Finally, ESOPs also cause employees to hold less diversified portfolios and have liquidity concerns. ESOP shares cannot be sold until employees leave the company, with the exception of diversification requirements triggered at 55 and 60 years of age. In equilibrium, these risks should increase employee compensation.

\section{Cash conservation}

Core and Guay (2001) find stock option plans for non-executive employees are often used at firms which appear cash-constrained. However, Oyer and Schaefer (2005) modify the procedure to identify broad based stock option plans and do not find evidence consistent with broad based stock options being used to ease financial constraints.

Issuing stocks through ESOPs can also relieve financial constraints by allowing the firm to substitute cash wages with stocks. Thus, we examine ESOPs implemented by cash constrained firms. If these ESOPs are indeed used to conserve cash, we expect lower cash wages following the implementation.

While the decision to substitute equity for cash wages may be optimal for firms facing cash shortage, it is doubtful that such plans will have the same uplifting effect on employee morale, team effects, and collective behavior as ESOPs by non-cash 
constrained firms. Thus, we expect these ESOPs to be associated with less productivity gains.

\section{Data}

Our data on ESOPs cover US public firms from 1980 through 2001. This data is hand-collected. We first identify firms with ESOPs, using the Factiva news database. For each year, we search Factiva using the terms "ESOP" and "employee stock ownership plan." We read all articles and note the first date a firm is mentioned as having an ESOP. We identify 756 unique public firms with ESOPs over the sample period. Of these firms, we drop 35 firms with total assets less than \$10 million in 2006 dollars. The lack of press coverage on such small firms makes it likely that we missed other similar-sized firms with ESOPs, wrongly identifying them as non-ESOP firms. This potential error is important as our control group is derived from firms in Compustat without identified ESOPs.

With the remaining 721 ESOP firms, we run additional Factiva searches using the firm's name and "employee stock" to locate further information on each firm's ESOP." When available, we record information on the ESOP initiation date. ${ }^{8} \mathrm{We}$ are able to identify the year of the ESOP initiation for 418 unique firms.

We determine the size of ESOPs by reading annual proxy statements for all firms with ESOPs. In most cases, ESOP share ownership is reported only if the plan has more

\footnotetext{
${ }^{7}$ In a few cases, this additional search led us to identify the presence of an ESOP in an earlier year. We exclude these observations to prevent a possible survivorship bias. Information about an ESOP may not have been discovered in our first search process if the firm was small and received limited press coverage. When the firm becomes more profitable and grows larger, press coverage becomes more likely, increasing the probability we observe the ESOP. This could cause a positive correlation between observed ESOPs and firm performance.

${ }^{8}$ If a firm underwent a bankruptcy or was dropped from Compustat for a year or more, we assume the ESOP was terminated unless other information is present.
} 
than $5 \%$ of the firm's common equity. We assume the ESOP controls less than $5 \%$ of the firm's outstanding shares if the proxy statement does not report specific numbers concerning ESOP size. The ESOP database is then matched to Compustat and Center for Research in Security Prices (CRSP) databases for accounting and stock market variables.

The ESOP database is also matched to the Longitudinal Business Database (LBD), a panel data set that tracks all U.S. business establishments with at least one employee or positive payroll from 1975 to the present, maintained by the U.S. Bureau of Census. The database is formed by linking years of the Business Register (formally called the standard statistical establishment list or SSEL.) The Business Register is a Census Bureau construct based primarily on information from the Internal Revenue Service of the U.S. Treasury Department. ${ }^{9}$ The Business Register contains information on the number of employees working for an establishment and total annual establishment payroll. The LBD links the establishments contained in the Business Register over time and can be matched to Compustat using a bridge file provided by the US Census.

This Census data is an improvement over the wage and employment data reported in Compustat. For one, the Census data is available at the establishment level which allows us to identify changes at one specific facility as opposed to having to rely on firmlevel data. Second, we are able to observe the state of location for each facility. This allows us to control for geography-dependant mean wages. Finally, many active firms in Compustat do not report the number of employees or their compensation. Wage data based on Compustat is unreliable because personnel information is subject to looser reporting and auditing requirements than financial variables.

\footnotetext{
${ }^{9}$ See Jarmin and Miranda (2002) for more information.
} 
We add to our ESOP sample a set of control firms, matched to our ESOP firms. For each ESOP firm, we calculate 1) total assets, 2) the average firm-level wage per employee, and 3) the change in average firm-level wage per employee prior to the ESOP initiation. The change in wages is used to ensure that the set of ESOP firms and matched firms exhibit a similar trend in wages prior to the year of matching. The change in wages is defined as $\left(\right.$ wages $_{\mathrm{t}-1}-$ wages $\left._{\mathrm{t}-2}\right) /$ wages $_{\mathrm{t}-2}$, where $\mathrm{t}$ is the year of ESOP initiation.

We estimate the same variables for a set of potential control firms, which includes all firms in the same industry, in the same year that never issued an ESOP. We estimate the absolute difference between the potential control firm and the ESOP firm on all three criteria. We sum up these differences and the control group is chosen as those firms with the smallest total differences. We identify the three nearest neighbor matches for each ESOP firm. However, since we identify the match for each ESOP firm from the same pool of firms, in some cases, a control firm is matched to multiple ESOP firms. To maintain a sample of independent observations, we require a match firm appear in the control group as a unique firm.

ESOP firms are included in our sample for the five years before and the ten years after the ESOP is initiated. We begin five years prior to the ESOP adoption to capture the most current information and extend to ten years afterward because ESOP shares must be granted to individual employee accounts within ten years. Observations after 10 years are excluded to reduce the impact of changes unrelated to the ESOP occurring well after the initiation. We also exclude observations after an ESOP termination to ensure that our baseline is not picking up post-termination effects. ${ }^{10}$ The same time series is calculated

\footnotetext{
${ }^{10}$ There are 56 ESOP terminations (138 plant-year observations) in our ESOP database. Terminating an ESOP is a complex legal procedure. The firm must be able to legally justify why the ESOP was value-
} 
for the matched group. We keep matched firms in our sample for the 5 years before and the 10 years after the match.

Table 1, Panel A, lists the number of new ESOP adoptions and observation counts in our ESOP database by year. It identifies 5,596 firm-year observations between 1980 and 2004 with the median ESOP having $5.93 \%$ of shares outstanding. ${ }^{11}$ Of the 418 ESOPs in our sample, 225 achieve a size of $5 \%$ or greater at some point during their lifetime. The median and the mean ownership of these large ESOPs is $12.18 \%$ and $16.65 \%$ of shares outstanding, respectively.

Panel B of Table 1 provides summary statistics of the relevant firm level variables. The first column details firms which will later initiate an ESOP, but in the years before the ESOP is initiated. The second column describes firms with ESOPs. The third column details firms with large ESOPs. An ESOP is considered large if, at any point during the lifetime of the plan, it has more than $5 \%$ of the outstanding common shares. We choose this demarcation point because proxy statements only detail the size if the ESOP has more than $5 \%$ of the firm's equity. In addition, $5 \%$ is often used as a threshold for various disclosure requirements, presumably because it signifies an important source of control rights. The fourth column summarizes the set of matched firms.

ESOP firms are more profitable and have higher leverage as compared to control firms. Furthermore, ESOP firms are larger and valued lower as measured by (industryadjusted) Tobin's Q. The lower valuation is most noticeable for large ESOP firms.

increasing for the firm in the past but is now value-decreasing; otherwise, it is open to lawsuits from ESOP holders and shareholders. Thus, it is more common to "freeze-out" an ESOP. A freeze-out is usually not announced officially and thus is hard to identify. In our sample, firms which are electing to freeze-out their ESOP will still be recorded as having an ESOP, which is literally true because the ESOP still exists. There are some firms that have rolled up their ESOP into a 401-K plan. Such 401-K plans may still be recorded in our database as an ESOP, which is not completely off-base because they still represent ESO.

${ }^{11}$ We cannot estimate the mean due to missing data on ESOP size for ESOPs with percentage share ownership less than $5 \%$. 
Financial leverage increases following ESOP initiation because they are often debt financed.

Panel C of Table 1 provides summary statistics of relevant payroll information at the establishment-level. As mentioned earlier, an establishment describes any facility with a separate physical address, such a factory, service station, restaurant, and so on. We include all establishments owned by either our ESOP group or the control group. Both pre-ESOP firms and ESOP firms have more employees per establishment than the control group. Wages are higher at pre-ESOP firms relative to the control sample and the difference between these firms is magnified post-ESOP. ${ }^{12}$

\section{Empirical results}

In this section we first estimate the relation between employee compensation and the presence of ESOPs, followed by an investigation of the relation between firm value and accounting performance and ESOPs.

\section{A. Employee compensation}

Our compensation data provides establishment-level annual payroll, which includes all taxable forms of compensation, such as salaries, wages, commissions, and bonuses. However, the compensation data does not include ESOP shares given to employees and, hence, underestimates the total compensation and benefits given to employees with ESOP shares. Our measure of wages per employee is the ratio of annual payroll (in thousand dollars, normalized to 2006 dollars) to the number of employees.

\section{A.1. Univariate Analysis}

\footnotetext{
${ }^{12}$ While the difference in wages per employee is more modest between pre-ESOP firms and the control sample, the difference of $\$ 829 /$ employee is still statistically significant.
} 
We begin by examining how wages change around the ESOP initiation. Table 2, Panel A provides a time series of average wages per employee (in thousands) over a fiveyear window surrounding the year of ESOP initiation, separately for small ESOPs, large ESOPs, and the control group. We use the log of wages per employee because wages are highly skewed. We do not consider years beyond the five-year window surrounding the year of ESOP initiation because the high rate of establishment entry and exit leads to significant changes to the sample over time. That is, the samples used to calculate the year 0 average and the year +5 averages are quite different. Notice, however, this is not a concern in the next section where regressions control for establishment-fixed effects.

Panel B of the Table reports abnormal wages that cannot be explained by wages in the state of location and by wages in the same industry in the same year. Unexplained wages is the residual from the following regression:

$$
\text { Wages }_{i t}=\alpha_{0}+\beta_{1} \text { state mean } \text { wages }_{i t}+\beta_{2} \text { industry mean } \text { wages }_{i t}+\mu_{i t}
$$

Subscripts $i$ and $t$ indicate establishment $\mathrm{i}$ and year $\mathrm{t}$, and wages are the log of wages per employee. State-year mean wage is the log mean wage per employee in the state of location of the establishment in the same year. Industry-year mean wage is the log mean wage per employee matched to the establishment's industry and by year. For the ESOP samples, relative year represents the year relative to when the ESOP was initiated (year 0). The control sample is created at the time of the ESOP initiation and then the control firms are followed over time. Thus, for the control sample, the relative year represents the year relative to when the firm was matched to an ESOP firm initiating an ESOP (year 0.) 
Both panels reveal a pattern of declining wages prior to the ESOP initiation. Comparing log wages in Panel A and abnormal wages in Panel B between year -2 and -1 show that wages are declining for both small and large ESOP firms. This may indicate that some ESOPs are implemented following years in which the firm is cash-constrained. One concern upon seeing this pre-initiation trend is that it may predict higher wages postESOP if wages follow a mean-reverting process. This is why we require firms included in our control group (non-ESOP issuers) to exhibit a similar decline in wages. This requirement is reflected in the last column of Panel A, where the control firms also show a decline in raw wages prior to Year 0.

This declining trend is reversed starting the year of ESOP initiation. Both the log and abnormal wages increase sharply in years 0,1 , and 2 for the set of ESOP firms. The $\log$ wages also increase for the control group; however, unlike the sample firms, the control group does not show any positive increase in abnormal wages. This difference between the sample and control groups suggests that workers enjoy higher wage increases following ESOP adoption.

\section{A.2. Multivariate Analysis}

The above analyses do not control for relevant establishment and firm characteristics. In this section, we estimate the relation between employee compensation at the establishment level and ESOPs with panel regressions using all treatment and control firms meeting our sample construction criteria over 1982 to $2001 .^{13}$ The baseline panel regression is:

$$
\text { Wages }_{i t}=\eta_{t}+\theta_{i}+\alpha_{0}+\alpha \text { ESOP }_{i t}+\beta Z_{i t}+\mu_{i t}
$$

\footnotetext{
${ }^{13}$ Our sample ends in 2001 because a change in Census data reporting of establishment-level identifiers in 2001 makes it difficult to link post-2001 observations to our earlier sample.
} 
Subscripts $i$ and $t$ indicate establishment $\mathrm{i}$ and year $\mathrm{t}$, and $\eta_{t}$ and $\theta_{i}$ are year- and establishment fixed effects. ESOP ${ }_{i t}$ includes ESOP and ESOPg5 indicators, and $Z_{i t}$ is a set of control variables. The wages at an establishment before an ESOP, as reflected in the establishment fixed effects, proxy for the expected wages in future years, had the ESOP not been adopted. To better isolate the effect of an ESOP on wages, we exclude the year of the announcement of ESOP adoption and the year after. The year of adoption is excluded because most ESOPs are not implemented on the first day of the firm's calendar year and thus this year of adoption captures both a pre-ESOP period and a post-ESOP period. The year after the adoption is also excluded because ESOP shares are allocated over several years and because Jones and Kato (1995) show that it takes about three years before ESOPs show effects on worker productivity. Thus, we are comparing pre-ESOP wages to post-ESOP wages, where post-ESOP wages are defined as those from year +2 to year +10 . Any cumulative effects of wage changes during years 0 and +1 are reflected in wages in year +2 .

The baseline regression contains two ESOP indicator variables: ESOP, equal to one if the firm has an ESOP; and ESOPg5, equal to one if, at its maximum, employees control more than $5 \%$ of outstanding shares through the ESOP. ${ }^{14}$ All compensation regressions control for establishment fixed effects and year fixed effects. Year fixed effects capture economy-wide changes in wages over time. Including establishment fixed effects allows us to control for time-invariant establishment characteristics.

The first column in Table 3 reports results of the panel regression with only establishment and year fixed effects. The coefficient on ESOP indicates that wages

\footnotetext{
${ }^{14}$ We use the maximum ESOP size to classify whether or not the observation is included in the ESOPg5 variable. As such, if an ESOP ever controls more than 5\% of the outstanding stock then this ESOP is classified as ESOPg5 for the lifetime of the ESOP.
} 
increase following the adoption of an ESOP. Since the value of the ESOP shares being allocated to employees is not included in our estimate of wages, this increase in wages at ESOP firms is in addition to the value of any ESOP shares allocated.

Wage increases following the adoption of an ESOP may reflect an increase in productivity following the creation of employee-owners, a conjecture consistent with the findings of Jones and Kato (1995) and Kruse, Freeman and Blasi (2009) that ESOPs increase worker productivity. It is also consistent with our prediction based on a rentsharing model that employees will capture a share of productivity gains

This result could also reflect time-varying characteristics in firms which elect to establish ESOPs. For example, a generous CEO may decide to give employees both higher wages and employee ownership shares in anticipation of future value gains or a sudden inspiration to become more generous. If implemented contemporaneously, the data would show a positive correlation between ESOPs and wages. Later tests in the paper reject this selection story in support of the causal interpretation of these results.

Column 1 also shows that the coefficient on ESOPg5 is negative, indicating that wage increases following large ESOPs are smaller than those following small ESOPs. This smaller increase in wages may reflect a substitution of ESOP shares for cash wages. Employees at firms with large ESOPs will realize greater value from the transfer of shares than employees at firms with small ESOPs. The average size of shares granted to employees through a large ESOP is $16.65 \%$ of the firm's market capitalization. The average market capitalization of a firm with a large ESOP is \$3.5B (in 2006\$) and has 48,000 employees. Thus, the average large ESOP has a total value of $\$ 583 \mathrm{M}$, which translates into $\$ 12,145$ per employee. Given that the average wage for workers at these 
large firms is $\$ 53,000$, the value of the ESOP shares allocated would represents $4.7 \%$ of annual wages if the shares were allocated equally over 5 years, or $2.35 \%$ if allocated over 10 years. Although workers will value ESOP shares less than cash wages, given the limitations on selling ESOP shares, the value of these shares are substantial. To reflect the value of these shares, cash wages may increase less, even decrease, following large ESOPs.

This substitution of ESOP shares for cash wages will be most likely to be observed at firms which are cash constrained. These firms may establish ESOPs specifically as a means to conserve cash, in which case cash wages would subsequently decline. In later tests we directly control for cash constraints at the time the ESOP was initiated.

Column 2 of Table 3 controls for changing local and industry conditions by adding two controls. The first is state-year mean wages, the mean value of the dependent variable in the state of location of an establishment in the same year, excluding the establishment itself from the mean. This variable controls for state-specific wage changes over time (see Bertrand and Mullainathan (2003)). Wages may also reflect changing industry conditions. Thus, we also control for industry-year mean wages. Industry-year mean wages are the mean wages of all establishments operating in the same industry as the establishment of interest (defined at the 3-digit SIC code level), but excluding this establishment itself, and matched by year. This variable controls for industry-specific changes in wages over time.

As expected, we observe a strong positive correlation between the establishmentlevel wages and 1) the average wages in the same state of location in the same year and 2) 
the average wages in the same industry and in the same year. With these additional controls, we continue to find a positive coefficient on ESOP and a negative coefficient on ESOPg5. The magnitude of coefficient on ESOP is decreased; furthermore, the negative coefficient on ESOPg5 becomes more negative. The results indicate that if one ignores the value of ESOP shares granted, there are no wage gains when ESOP size is large and wages gains are limited to only small ESOPs.

Column 3 adds establishment age, sales at the firm-level, and firm leverage as further controls. Establishment age and wages are positively correlated, indicating that older establishments have higher wages. We observe no relation between firm sales and wages. We also control for leverage as ESOPs are often associated with increases in firm leverage. We find wages are lower when leverage is high. In a later section, we provide a further analysis on the relation between wage changes and leverage.

The coefficients on ESOP and ESOPg5 hardly change from those in column 2, demonstrating the robustness of these results. The coefficients in column 3 imply that wages at firms which initiate small ESOPs increase by $6.1 \%$ or by $\$ 3,114$ (in $2006 \$$ ) for the average worker. The wages at firms initiating large ESOPs, by contrast, decline by $1.6 \%$ or by $\$ 848$ (in $2006 \$$ ) for the average worker. However, this decline is likely to be smaller than the value of ESOP shares granted to employees; thus, we conclude total employee compensation changes following large ESOPs are non-negative. The regression specification in column 3 will be used as the baseline model for wage regressions throughout the rest of the paper.

The remaining columns in Table 3 are further robustness checks. In column 4, we examine whether the results are being driven by the selection of the control firms. One 
way to check the possibility is to drop the control firms and estimate the regression using only the set of firms which have an ESOP at one point in time. Column 4 reports the results. Although the magnitude of coefficients change, the principle finding of higher wages following an initiation of small ESOPs and the negative sign on large ESOPs continues to hold.

Wages are reported at the establishment-level. However, wages at establishments owned by the same firm may be correlated, over-stating the number of independent observations and under-stating the standard errors. To address this concern, we repeat columns 3 and 4 with clustered standard errors at the firm-level in columns 5 and 6 . Although the statistical significance is lower, the findings in columns 3 and 4 continue to hold. The drop in statistical significance is due to the fact that our sample contains only 418 firms with identifiable ESOP initiation years.

\section{B. Firm Valuation and Accounting Returns}

With these wages changes associated with the implementation of ESOPs, how do ESOPs affect shareholder value? To investigate this issue, we estimate a panel regression relating firm valuation and operating profitability to indicator variables for the presence of ESOPs. Firm valuation is proxied by industry adjusted Tobin's $\mathrm{Q}_{\mathrm{it}}$. Tobin's Q is measured as fiscal year-end market value of equity plus market value of preferred stock plus total liabilities divided by the book value of total assets. We follow Bebchuk and Cohen (2005) and use industry adjusted Q by subtracting the median Q matched by industry (3-digit SIC code) and year. The baseline panel regression is:

$$
\operatorname{Ind}-\operatorname{Adj} Q_{i t}=\eta_{t}+\theta_{i}+\alpha_{0}+\alpha E S O P_{i t}+\beta Z_{i t}+\mu_{i t}
$$


Subscripts $i$ and $t$ indicate firm i and year t, and $\eta_{t}$ and $\theta_{i}$ are year- and firm fixed effects. $E S O P{ }_{i t}$ includes ESOP and ESOPg5, and $Z_{i t}$ is a set of control variables. We include firm fixed effects to control for time-invariant firm characteristics. We also control for time series patterns with year fixed effects. The initial set of control variables include the log of total assets and the log of sales (both normalized in 2006 dollars).

We use the same ESOP sample and control group as with our compensation regressions. The only difference is that this is firm-level data as opposed to establishment-level data. Column 1 of Table 4 shows that the presence of an ESOP is associated with a statistically positive increase in industry adjusted Q.

Column 2 includes ESOPg5, which shows a significant negative sign. Because the coefficients on the ESOP indicator variables are cumulative, the combined coefficient on ESOPg5 is $0.174-0.175$, or -0.001 . To determine if large plans are associated with an overall firm value effect, we enter ESOPg 5 alone in column 3 and find an insignificant coefficient.

These estimation results suggest that small ESOPs increase firm value but large ESOPs have neutral effects. The positive coefficient on the ESOP indicator suggests that firms establishing small ESOPs realize about $17 \%$ increase in firm valuation relative to the sample mean. ${ }^{15}$ This is true only when the ESOP size is less than $5 \%$ of the outstanding shares; otherwise, there are no valuation consequences.

The remaining columns in Table 4 are robustness tests using additional controls. The sample used in these tests includes the same set of ESOP firms but a different set of

\footnotetext{
15 This result on small ESOPs does not necessarily imply that firms can increase shareholder value by $17 \%$ by adopting an ESOP. Firms adopting small ESOPs may do so because they expect greater valuation effects than non-ESOP firms; as such, our estimation may represent the upper tail of possible valuation impacts.
} 
control firms. The control firms are matched by industry, year, and size. They are also matched by industry-adjusted $\mathrm{Q}$ but are not matched by wages and wage changes. ${ }^{16}$ Columns 4-6 include additional firm level variables as controls: R\&D/Sales, the ratio of R\&D expenditures to sales; CapEx/Assets, the ratio of capital expenditures to total assets; Log Firm Age, the log of firm age; Sigma, firm idiosyncratic risk measured as the standard error of the residuals from a CAPM model estimated using daily data over the fiscal year; and SigmaDum, a dummy variable which takes the value of 1 if the data to estimate Sigma is available, and zero otherwise. ${ }^{17}$ Previous studies using regressions with firm- and year fixed effects (e.g., Himmelberg, Hubbard, and Palia (1999)) document significant correlations between these variables and Tobin's Q. Firm idiosyncratic risk is included because it may affect the attractiveness of ESOP shares to employees. Holding company stock reduces personal diversification; thus, everything being equal, the riskier the company stock, the less will the ESOP shares be valued by employees.

Column 4 includes the log of total assets in addition to the observable firm-level variables. However, Coles, Lemmon, and Meschke (2007) note that regression results of managerial ownership on Tobin's Q are sensitive to both the definition of and inclusion of non-linear size controls. Column 5 includes both assets and assets squared; and column 6 , sales and sales squared. The results are robust to all of these additional controls.

\footnotetext{
${ }^{16}$ To match by wages and wage changes requires the use of confidential data and a lengthy disclosure process by the US Census. We are in the process of re-estimating the regressions in these columns using the same set of control firms described earlier, and have not yet obtained the necessary clearance to disclose the results at the time of writing this draft.

${ }^{17}$ The is the method used by Himmelberg, Hubbard, and Palia (1999) to avoid reducing the sample size due to missing data.
} 
In columns 7 and 8 , we repeat our tests using a measure of operating profits as the dependent variable. Unlike Tobin's Q, the profit variable, measured by industry-adjusted operating income divided by total assets, is an accounting based variable that provides an alternative measure of firm performance. The results are consistent with our evidence using Tobin's Q, firm operating performance increases following the adoption of a small ESOP and is essentially flat following the adoption of a large ESOP.

\section{An Interim Summary}

Our results so far suggest that small ESOPs, defined as those controlling less than $5 \%$ of shares outstanding, increase both employee wages and shareholder value. We infer from this evidence that small ESOPs increase worker productivity and the gains are shared by employees and shareholders. Large ESOPs, by contrast, increase neither employee wages nor shareholder value. Although the total effects on employee compensation and benefits may be positive if we include the value of ESOP shares granted to employees, the results for large ESOPs suggest much more modest productivity gains. Why the size makes such a difference is the puzzle we attempt to resolve in the next section.

\section{Alternative Motives for Large ESOPs}

There are two possible explanations for the puzzle. The first is that giving too much control rights to workers negates the potential productivity gains arising from improved team effects and collective employee behavior arising from employee ownership. Namely, too much employee control rights permeate corporate socialism, negating the benefits of employee capitalism. The second is a selection story: Small 
ESOPs are motivated to increase worker productivity, whereas many large ESOPs are motivated by non-value creating considerations.

These two explanations are not mutually exclusive. We explore two non-value creating motives for large ESOPs: Substitution of cash wages with ESOP shares by cash constrained firms, and management-worker alliance to thwart hostile takeover bids. The management-worker alliance is a specific form of employee socialism that arises from intentional bestowment of large control rights to employees by the management. Neither motivation is likely to apply to small ESOPs. If the primary purpose is to conserve cash by substituting ESOP shares for cash wages, meaningful cash conservation requires large ESOPs. If the purpose is to form a management-worker alliance through an ESOP, making employees an effective partner requires the ESOP to bestow substantial control rights to workers. In Tables 5 and 6, we explore these conjectures with proxies for large ESOPs motivated by cash conservation and management-worker alliance.

Our estimation of the wage changes following an ESOP underestimates the impact of ESOPs on total employee compensation and benefits because our wage data does not include the value of shares granted to employees. This underestimation will be particularly important if firms are substituting ESOP shares for wages to conserve cash. Such an ESOP may lead to substantially lower post-ESOP cash wages.

To identify ESOPs motivated to conserve cash, we follow Hadlock and Pierce (2009) and identify cash constrained firms as young firms with small assets. We define this variable only for firms initiating large ESOPs because cash conservation is unlikely to apply to small ESOPS. We define two variables, "ESOPcc" and "CCindex". ESOPcc is a dummy variable which takes a value of 1 if a firm has a large ESOP and the firm was 
in the bottom half of the sample by both assets and age at the time of implementing the ESOP.

CCindex is a continuous variable which measures how young and small a firm is, relative to the rest of the sample, at the time the large ESOP was initiated. To construct CCindex, we estimate the difference in both the firm age and firm size (total assets in 2006 \$) as compared to the sample means. Both of these differences are then normalized by the sample standard deviation for that variable. ${ }^{18}$ These two variables are then summed to create a credit constrained score. Because this score is highly skewed, we do not directly use this score; instead, we create a ranking based on each firm's cash constrained score. This ranked variable is the "CCindex," which awards the highest value to the firm which is the youngest and smallest. This variable is only estimated for firms establishing the large ESOPs, and is set to 0 for firms without large ESOPs.

The management-worker alliance hypothesis is based on Pagano and Volpin (2005), which theorizes that managers concerned with hostile takeover threats bribe workers with above-market wages in return for their cooperation in fending off hostile bids. When employee-owners are bestowed with substantial control rights through large ESOPs, they may use the rights to help management in thwarting hostile takeover bids. To garner worker support, management in turn may reward workers with higher cash wages and/or ESOPs shares. Such management-worker alliance through ESOPs is especially relevant to companies subject to Business Combination Statutes (BCS). BCS state that if a block of investors, unaffiliated with management, vote against a tender offer, the bidder must wait three to five years before pursuing the takeover. Because courts

\footnotetext{
${ }^{18}$ For firm age, this variable is calculated as: [Firm age - mean age]/sample standard deviation of age. The same normalization process is used for firm size
} 
have established ESOPs as "outside" investors, BCS make large ESOPs an effective antitakeover device. We expect this type of ESOP to be followed by significant wage gains. To test this prediction, we use two strategies. Initially, we predict that large ESOPs implemented under takeover pressure lead to higher worker compensation. In the next section, we explicitly take into account the effect BCS has on the efficiency of ESOPs as an anti-takeover device and examine the interactive effects of ESOPs with the enactment of BCS.

We identify whether an ESOP is established under takeover pressure by an indicator variable, TO, which assumes a value of one if the firm has an ESOP and this ESOP was established during a takeover battle. The source of information is Blasi and Kruse (1991), which identifies an ESOP as being implemented during a takeover battle based on public documents. As such, TO is an imperfect measure of whether or not an ESOP was implemented during a takeover battle. Some firms may have been under takeover pressure when they initiated ESOPs, but no public record was made of the takeover possibilities. Such ESOPs will not be included in our proxy TO. Furthermore, since the source was published in 1991, all ESOPs established after 1990 are classified as being under no takeover pressure. As such, many other ESOPs implemented under takeover pressure are not captured by the TO variable.

In Table 5, we report the wage regression estimation results with ESOPcc, CCindex, and TO. All regressions include establishment and year fixed effects, log establishment age, state-year mean wages, industry-year mean wages, log sales, and leverage. The coefficients on these control variables are not reported. 
Column 1 shows a negative coefficient on ESOPg5 and a negative coefficient on ESOPcc. Since ESOPcc is a subset of ESOPg5, the coefficient on ESOPcc is additive. Thus, large ESOPs initiated by cash constrained firms are associated with 12\% lower wages, relative to large ESOPs initiated by non-cash constrained firms. These results indicate that much of the wage declines following large ESOPs can be attributed to those firms which appear to be cash-constrained.

In column 2, we exclude the variable ESOP. By estimating the coefficient on ESOPg5 and ESOPcc without ESOP, we estimate the net correlation between employee wages and large ESOPs. The result is a small negative coefficient on ESOPg5, and a large and negative coefficient on ESOPcc. The negative coefficient of 1.7\% on ESOPg5 is likely to be offset by the value of ESOP shares granted in large ESOPs. Thus, we conclude that large ESOPs implemented by non-cash-constrained firms have no negative effect of total employee compensation.

In columns 3-5 we use our continuous measure of cash constraints, CCindex, at those firms which implement large ESOPs. ${ }^{19}$ As predicted, the coefficient on CCindex is negative and significant, which implies that for firms establishing large ESOPs, the more cash constrained the firm, the more cash wages decline afterward. This is consistent with our conjecture that cash constrained firms are more likely to initiate ESOPs as a means to shift cash wages to ESOP shares.

Column 3 also reports a negative coefficient on TO, which is inconsistent with the prediction of the management-worker alliance hypothesis. Takeover-motivated ESOPs

\footnotetext{
${ }^{19}$ Due to disclosure issues regarding the use of confidential data, we need to use a continuous measure of cash constraints when estimating the dummy variable TO. The concern is that including 4 dummy variables in one regression: ESOP, ESOPg5, ESOPcc and TO will lead to the possible identification of confidential wage data for individual firms.
} 
tend to be larger because an effective alliance requires a large worker control rights; thus, the underestimation of worker compensation due to our inability to account for the value of ESOP shares is larger. The results also mask an important heterogeneity across firms subject to different degrees of product market competition.

\section{E. Interactive Effects with Product Market Competition}

The management-worker alliance through an ESOP represents managementemployee entrenchment. Such entrenchment may not be sustainable if strong product market competition limits managerial slack. Guadalupe and Wulf (2007) provide evidence that product market competition improves governance, and Giroud and Mueller (2009) demonstrate that product market competition serves as an effective external governance mechanism. Thus, we hypothesize that the management-worker alliance is more likely among firms operating in product markets with weak competition.

To measure the competitiveness within a firm's industry, we estimate the industry concentration by developing an employee-based Herfindahl-Hirschman Index (eHHI). This index is created in a similar manner as a traditional sales-based HHI, except that the measure is based on the fraction of the industry's labor force employed at a firm rather than the fraction of industry sales attributable to a firm.

The benefit of this employee based index over sales-based index using Compustat is that our index includes all firms, avoiding the error due to the exclusion of private firms (Maksimovic and Phillips, 2001; Ali, Klasa and Yeung 2008). The Economic Census also releases its own HHI, but it includes only manufacturing industries, which will cut our sample size by over $80 \%$. For these reasons, we create our own index based on the number of employees. 
Our eHHI is calculated as follows. In the first step, we identify the primary industry associated with a firm. The Census databases only report establishment-level data. As such, we have information on the SIC codes for all of the establishments linked to a firm but do not have a single firm-level SIC code. To identify the primary industry associated with a firm, we sum the total workers at all of the establishments linked to a firm, per 3-digit SIC code. We then define the firm's industry as the 3-digit SIC code which captures the largest fraction of the firm's total workforce and assign all of the firm's employees to this firm-level 3-digit SIC code.

We identify the total employee count for each industry as the sum of the employees at all firms assigned to that industry. The employee market share of an individual firm is defined as the firm's employees divided by the total employees in that industry. The eHHI is then estimated as the sum of the squares of the employee market share of all firms in that 3-digit SIC code. ${ }^{20} \mathrm{~A}$ firm is defined as being in a high or low eHHI industry by whether or not its reported industry has an eHHI score above or below the sample median. ${ }^{21}$ All establishments affiliated with a firm are assigned to the same high HHI or low HHI regardless of the establishment-level industry. ${ }^{22}$

Based on this classification of industry competitiveness, we repeat the regressions for high eHHI firms in column 4, and for low eHHI firms in column 5 in Table 5. The results reveal that the negative coefficient on TO in column 3 is driven by firms in highly competitive industries (low eHHI). For firms in low competition industries (high eHHI),

\footnotetext{
${ }^{20}$ The eHHI index has a correlation of $22.6 \%$ with a traditional sales-based Herfindahl-Hirschman index calculated using Compustat data.

${ }^{21}$ The median is estimated over the set of ESOP firm-years. Thus, half the ESOP firm-year observations are in the eHHI high and half in the eHHI low group. The eHHI high group has more establishment-year observations, indicating sample firms in more concentrated industries tend to have more establishments as compared to firms in more competitive industries.

${ }^{22}$ However, a firm can switch from eHHI high to eHHI low over time (or vice versa).
} 
TO shows a positive and significant coefficient. This is consistent with the managementworker alliance hypothesis, which predicts higher wages following an ESOP initiation.

As for firms in highly competitive industry, they do not have much slack to start with. Hence, to appease shareholders, they may undertake restructuring measures, including wage cuts, as a part of defensive maneuver. Or some of these firms were taken over, and successful acquirers may have cut wages as a part of post-acquisition restructuring measures.

The results in columns 4 and 5 also allow us to distinguish between the selection and causal interpretation of the observed wage gains following the initiation of small ESOPs. If the generous manager story is driving our results, then we would expect to observe higher wage gains following small ESOPs in non-competitive industries (high eHHI) because only in these industries will managers have sufficient slack to be generous. Presumably, in competitive industries (low eHHI), a generous manager will be driven out of business. Column 4 shows no wage gains following small ESOPs at firms in noncompetitive industries. ${ }^{23}$ This is inconsistent with the generous manager story.

In contrast, our causal story based on a rent-sharing model predicts that employees in competitive markets will capture more of the surplus associated with productivity gains. The rent sharing model suggests that workers will shirk, or even quit, if they do not receive a fair share of their productivity gains. In the cross-section, this threat to shirk and quit will matter more, the more competitive the labor market. Assuming workers prefer to remain employed in the same industry due to industryspecific human capital, any decision to shirk, which can lead to firing, or to quit will

\footnotetext{
${ }^{23}$ We find similar results when using a conventional sales-based Herfindahl index as estimated using only public firms.
} 
depend on the outside employment opportunity in the same industry. Recall that eHHI is a direct measure of the labor concentration within an industry and, hence, can be considered a measure of labor market competitiveness. Thus, employees in concentrated industries have fewer outside employment opportunities, which means greater bargaining power to employers (Bhaskar, Manning, and To, 2002; Manning, 2003). With greater bargaining power, employers in concentrated industries will face fewer threats to shirk or quit over wages and, thus, will be able to retain more of the surplus for shareholders. In contrast, employers in industries with a competitive market for labor will have to share a larger fraction of the surplus with employees to retain them. Thus, we expect the wage gains following the adoption of small ESOPs to be concentrated in competitive industries.

The evidence in columns 4 and 5 is consistent with the causal interpretation of our results. The coefficient on ESOP in column 5 shows that the wage gains associated with small ESOPs are concentrated at firms in competitive industries (low eHHI). Employees working in a high eHHI have fewer outside employers and, thus, are less likely to quit if dissatisfied with their wages. This will limit the ability of employees working in high concentration industries to share in the gains associated with ESOP-related productivity increases.

\section{F. Large ESOPs and Management-Worker Alliance - Further Evidence}

In this section, we conduct a more refined test on the worker-management alliance hypothesis by examining how ESOPs interact with the enactment of business combination statutes (BCS) and with financial leverage. BCS are regulations enacted at the state level in a staggered fashion during our sample period. As mentioned earlier, the passage of the laws makes ESOPs particularly effective takeover deterrents. Furthermore, 
Bertrand and Mullainathan (2003) argue that the enactment of BCS is exogenous to most firms incorporated in the affected states.

If managers use the ESOP to form an alliance with workers, then as workers become more influential post-BCS, they should receive higher compensation. However, if our results are non-causal and a generous manager is using a large ESOP to increase compensation, then the passage of the BCS per se should have no impact.

Bertrand and Mullainathan (2003) document significant increases in employee compensation following the enactment of BCS, which they attribute to management's pursuit of quiet lives after BCS relieve them of the threat of hostile takeovers. Our sample shows that $76 \%$ of ESOPs initiated after 1985, when New York State first passed BCS, are established by companies incorporated in states with BCS in effect. Thus, it is possible that the wage gains post-ESOP may not be ESOP-specific and instead are picking up the fact that our EOSPs are concentrated in BCS states. Thus, we first check whether the compensation increases accompanying ESOPs are reflecting the state-wide BCS effect.

In Table 6, we re-estimate the baseline wage regression while controlling for whether an establishment-year observation belongs to a firm incorporated in a state with BCS in effect. The regression specification is similar to the differences-in-differences like approach used by Bertrand and Mullainathan (2003), although data and some control variables are different from theirs. ${ }^{24}$ Column 1 shows a positive but insignificant coefficient on BCS. Also important, the coefficient estimates for both small and large

\footnotetext{
${ }^{24}$ Our estimate of BCS effect on wages is smaller than those reported by Bertrand and Mullainathan (2003), because we use a different dataset over a different time period. While Bertrand and Mullainathan (2003) examine all firms in manufacturing industries, our database covers all industries but we limit to ESOP firms and our control firms.
} 
ESOPs remain significant, with the magnitudes virtually unchanged from those in Table 3, column 3.

Column 1 indicates that BCS per se has no effect on worker wages for the average firm in the sample, a mix of ESOP firms and control firms. However, the effect of BCS adoption may differ between ESOP firms and control firms. Specifically, we predict the passage of BCS will have the greatest effect on those firms with large ESOP, given that BCS makes large ESOPs particularly effective anti-takeover device. We focus on large ESOPs by firms in concentrated industries because as discussed earlier, managementworker alliances are more likely to occur in concentrated industries.

We expect ESOPs initiated as a part of worker-management alliances to be followed by wage increases and the wage increases to be greater following the passage of BCS. This prediction is consistent with the results reported in column 2. The interaction of BCS and ESOPg5 shows a positive significant coefficient, indicating that wages at firms with large ESOPs increase following BCS passage. This evidence supports our hypothesis that at least some of the large ESOPs in concentrated industries reflect worker-management alliances. As for small ESOPs, there is no evidence of managementworker alliance. ${ }^{25}$

In column 3, we consider and rule out an alternative interpretation of the findings in column 2. An alternative explanation of the results in column 2 would suggest that the positive wage gains associated with small ESOPs and the negative wage gains associated with large ESOPs are strongest immediately after the ESOP is initiated and then become diluted over time. The effect of the ESOP may become diluted over time as employees

\footnotetext{
${ }^{25}$ The interaction term of ESOP and BCS shows a small negative sign but its statistical significance is only at the 10 percent level in spite of the large sample size.
} 
leave the firm with their shares. If true, we would expect any dummy variable which picks up firm-year ESOP observations with a greater average distance from the ESOP initiation will be biased towards 0 . This potential bias is applicable to the results in column 2 since BCS laws were passed over time and never repealed. As such, the average year distance relative to ESOP initiation for the sample captured in the BCS*ESOP interaction dummy variable will always be greater than the average year distance relative to ESOP initiation for the sample captured by the ESOP dummy variable. To consider this possibility, we directly control for the time since the ESOP was initiated with two variables, yeardif and yeardifg5. Yeardif is the number of years since the initiation of an ESOP, and is set to 0 for firms without ESOPs. Yeardifg5 is the number of years since the initiation of a large ESOP, and is set to 0 for firms without large ESOPs.

The results are reported in column 3. The evidence is consistent with our suspicion that the wage changes associated with ESOPs are diluted over time. However, the coefficient on the interaction of ESOPg5 and BCS remains positive and significant indicating that this result is not simply reflecting dilution over time.

Our final evidence to buttress the causal interpretation of the compensation increases is based on the disciplining role of financial leverage. Bronars and Deere (1991) argue with supporting evidence that the ability of unions to extract concessions from shareholders can be limited by high financial leverage because of its implied threat of bankruptcy. According to this argument, workers' ability to use the control rights bestowed by a large ESOP will be weaker if the firm has high financial leverage. That is, employee compensation increases following ESOPs will be smaller at firms with higher leverage. 
To test this prediction, we again focus on ESOPs most likely to be motivated to achieve a worker-management alliance; namely, large ESOPs initiated by firms in noncompetitive industries. In column 4, leverage is interacted with ESOP and ESOPg5. The regression estimate shows a negative and significant coefficient on the interaction of ESOPg5 and leverage. The threat of bankruptcy implied by high leverage seems to suppress employee-owners' ability to extract higher wages even when they have substantial control rights.

\section{G. Firm Valuation and Product Market Competition}

If the ways in which wages are affected by ESOPs depend on the strength of product market competition, is the firm performance relation with the size of ESOPs also affected by product market competition? Assuming everything else equal, a simple comparison of the ESOP and ESOPg5 coefficients between Tables 4 and 5 provides a hint: For low competition industries (eHHI high), they suggest that the valuation relation will be similar to those in Table 4, because Table 5 shows no relation between wages and ESOPs. For high competition industries (eHHI low), they suggest that the valuation relation will be considerably weaker than those in Table 4 , because the relation between wages and ESOPs show the same pattern as the relation between Q and ESOPs.

This is precisely what we find when we re-estimate the firm performance regression while dividing the sample into eHHI high and eHHI low groups in Table 7. To be consistent with Table 5, the regressions also control for cash constraints. When product market competition is weak (eHHI high), small ESOPs substantially increase firm value; firm value increases by $26 \%$ relative to the sample mean. Weak product market allows more slacks, which can be reduced by improving team effects and 
collective employee behavior by making them owner-employees. The reduction in slack will enhance firm performance.

When product market competition is strong (eHHI low), the positive valuation impact small ESOPs have is much smaller at $8 \%$ with $10 \%$ statistical significance. When firms operate in a highly competitive environment, survival requires high efficiency, leaving little room for improvement through employee and team incentives. Thus, the potential gain to shareholders is also small. ${ }^{26}$

\section{Conclusion}

In this paper we investigate whether adopting broad-based employee stock ownership enhances firm performance by improving employee incentives and team effects. That is, does employee capitalism work? If so, how are gains divided between shareholders and employees?

We find that small ESOPs increase productivity. However, unlike the evidence of Jones and Kato (1995) on Japanese ESOPs, our evidence of productivity gains is obtained by estimating the effects on two main beneficiaries of such gains; namely, employees and shareholders. Because both gain from adopting small ESOPs, we infer employee share ownership improves worker productivity.

A closer examination reveals that employees capture the lion's share of productivity gains in competitive industries, whereas shareholders capture most of the gains in concentrated industries. We interpret this as product market competition also affecting within industry job mobility. A competitive industry means more alternative employers, enabling workers to share a greater portion of their productivity gains. A

\footnotetext{
${ }^{26} \mathrm{We}$ are awaiting disclosure of results comparing operating profit returns by industry concentration.
} 
concentrated industry, on the other hand, means less within industry worker mobility, strengthening shareholders position during wage negotiations.

Large ESOPs, defined as those controlling more than $5 \%$ of shares outstanding, have a more or less neutral effect on both employee compensation and shareholder value, suggesting little productivity gains. This difference between small and large ESOPs can be explained by non-value creating motives specific to large ESOPs: Means to fend off hostile takeover bids and to conserve cash by cash constrained firms. When large ESOPs are used for these purposes, they do not improve team effects or collective employee behaviors that are necessary for worker productivity gains.

Finally, even when ESOPs are adopted to form worker-management alliances, a form of corporate socialism, we find no evidence that employees are able to extract unearned compensation increases. Although there might be some exceptions, the neutral effects large ESOPs have on shareholder value does not support the notion that broad based employee share ownership leads to value destroying corporate socialism. 


\section{References}

Akerlof, G., and Yellen, J., 1990. The fair wage-effort hypothesis and unemployment. Quarterly Journal of Economics 105:225-283.

Ali, A., Klasa, S., and Yeung, E., 2008. The limitations of industry concentration measures constructed with Compustat data: Implications for finance research. The Review of Financial Studies, forthcoming

Atanassov, J., and Kim, E. H., 2007. Labor and corporate governance: International evidence from restructuring decisions. The Journal of Finance, forthcoming.

Beatty, A., 1995. The cash flow and informational effects of employee stock ownership plans. Journal of Financial Economics 38:211-240.

Bebchuk, L., and Cohen, A., 2005. The costs of entrenched boards. Journal of Financial Economics 78:409-433.

Bertrand, M., and Mullainathan, S., 2003. Enjoying the quiet life? Corporate governance and managerial preferences. Journal of Political Economy 111:1043-1075.

Bertrand, M., and Mullainathan, S., 1999. Is there discretion in wage setting? A test using takeover legislation. RAND Journal of Economics 30:535-554.

Bhaskar, V., Manning, A., and To, T., 2002. Oligopsony and Monopsonistic Competition in Labor Markets. Journal of Economic Perspectives 16:155-174.

Blasi, J., Conte, M., and Kruse, D., 1996. Employee stock ownership and corporate performance among public companies. Industrial \& Labor Relations Review 50:60-79.

Blasi, J., and Kruse, D., 1991. The New Owners: The Mass Emergency of Employee Ownership in Public Companies and What it Means to American Business. New York: HarperCollins, 1991.

Bronars, S., and Deere, D., 1991. The threat of unionization, the use of debt, and the preservation of shareholder wealth. The Quarterly Journal of Economics 106:231-254.

Chang, S., and Mayers, D., 1992. Managerial vote ownership and shareholder wealth: Evidence from employee stock ownership plans. Journal of Financial Economics 32:103132.

Chaplinsky, S., and Niehaus, G., 1994. The role of ESOPs in takeover contests. The Journal of Finance 49:1451-1470.

Coles, J., Lemmon, M., and Meschke, F., 2007. Structural models and endogeneity in corporate finance: The link between managerial ownership and corporate performance, working paper. 
Core, J., and Guay, W., 2001. Stock option plans for non-executive employees. Journal of Financial Economics 61:253-287.

Cramton, P., and Mehran, H., Tracy, J., 2007. ESOP fables: The impact of employee stock ownership plans on labor disputes. Federal Reserve Bank of New York Working Paper.

Faleye, O., Mehrotra, V., Morck, R., 2006. When labor has a voice in corporate governance. Journal of Financial and Quantitative Analysis 41:489-510.

FitzRoy, F., and Kraft, K., 1987. Cooperation productivity and profit sharing, Quarterly Journal of Economics 102: 23-35.

Giroud, X., and Mueller, H., 2009. Does corporate governance matter in competitive industries? Journal of Financial Economics, forthcoming.

Gordon, L., and Pound, J., 1990. ESOPs and corporate control. The Journal of Financial Economics 27:525-555.

Guadalupe, M., and Wulf, J., 2007. The flattening firm and product market competition: The effect on trade liberalization. Columbia University Working Paper.

Hadlock, C., and Pierce, J., 2009. New evidence on measuring financial constraints:

Moving beyond the KZ index. Review of Financial Studies, forthcoming.

Hildreth, A., and Oswald, A., 1997. Rent-sharing and wages: Evidence from company and establishment panels. Journal of Labor Economics 15:318-337.

Himmelberg, C., Hubbard, R., and Palia, D., 1999. Understanding the determinants of managerial ownership and the link between ownership and performance. Journal of Financial Economics 53:353-384.

Jarmin, R., and Miranda, J., 2002. The Longitudinal Business Database. CES Working Paper No. 02-17.

Jones, D., and Kato, T., 1993. The scope, nature, and effects of employee stock ownership plans in Japan. Industrial and Labor Relations Review 46: 352-367.

Jones, D., and Kato, T., 1995. The productivity effects of employee stock-ownership plans and bonuses: Evidence from Japan. The American Economic Review 85:391-414.

Kandel, E., and Lazear, E., 1992. Peer pressure and partnerships. Journal of Political Economy 100:801-817. 
Kruse, D., Blasi, J., and Park, R., 2009. Shared capitalism in the US economy: Prevalence, characteristics, and employee views of financial participation in enterprises. In Shared Capitalism at Work: Employee Ownership, Profit and Gain Sharing, and Broadbased Stock Options. Forthcoming book.

Kruse, D., Freeman, R., and Blasi, J., 2009. Shared Capitalism at Work: Employee Ownership, Profit and Gain Sharing, and Broadbased Stock Options. Forthcoming book.

Maksimovic, V., and Phillips, G., 2001. The market for corporate assets: who engages in mergers and asset sales and are there efficiency gains? Journal of Finance 56:2019-2065.

Manning, A. 2003. Monopsony in Motion: Imperfect competition in labor markets. Princeton University Press. Princeton, NJ.

Oyer, P., and Schaefer, S., 2005. Why do some firms give stock options to all employees ?: An empirical examination of alternative theories. Journal of Financial Economics 76 :99-133.

Pagano, M., and Volpin, P. F., 2005. Managers, workers, and corporate control. The Journal of Finance 60:841-868. 
Table 1. Panel A. Summary Statistics of Employee Stock Ownership Plans (ESOPs) by Year. Counts of observations and average size of employee ownership summarized over time.

\begin{tabular}{|c|c|c|}
\hline Fiscal Year & ESOP Initiations & $\begin{array}{l}\text { Count of ESOP firm- } \\
\text { year observations }\end{array}$ \\
\hline 1980 & 2 & 4 \\
\hline 1981 & 0 & 4 \\
\hline 1982 & 2 & 6 \\
\hline 1983 & 5 & 13 \\
\hline 1984 & 8 & 22 \\
\hline 1985 & 13 & 38 \\
\hline 1986 & 14 & 50 \\
\hline 1987 & 24 & 72 \\
\hline 1988 & 36 & 105 \\
\hline 1989 & 82 & 189 \\
\hline 1990 & 53 & 247 \\
\hline 1991 & 16 & 262 \\
\hline 1992 & 22 & 275 \\
\hline 1993 & 10 & 314 \\
\hline 1994 & 24 & 332 \\
\hline 1995 & 15 & 349 \\
\hline 1996 & 26 & 388 \\
\hline 1997 & 18 & 396 \\
\hline 1998 & 16 & 393 \\
\hline 1999 & 17 & 396 \\
\hline 2000 & 7 & 381 \\
\hline 2001 & 2 & 362 \\
\hline 2002 & 1 & 355 \\
\hline 2003 & 3 & 347 \\
\hline 2004 & 2 & 296 \\
\hline Total & 418 & 5,596 \\
\hline
\end{tabular}


Table 1. Panel B. Firm-level summary statistics for ESOP firms and matched group. Accounting variables are from Compustat. All variables are winsorized at the 1\%. Assets and sales are normalized to $\$ 2006$. $Q_{\text {it }}$ is fiscal year-end market value of equity plus market value of preferred stock plus total liabilities divided by total assets. We follow Bebchuk and Cohen (2005) and industry adjust $Q$ by subtracting the median $Q$ matched by industry (3-digit SIC code) and year. Means are reported with median in parenthesis and standard deviations in brackets.

\begin{tabular}{|c|c|c|c|c|}
\hline & $\begin{array}{l}\text { Firms which later } \\
\text { adopt ESOPs }\end{array}$ & Firms with ESOPs & Firms with ESOPg5 & Matched Firms \\
\hline $\begin{array}{l}\text { Operating } \\
\text { Income/Assets }\end{array}$ & $\begin{array}{c}0.129 \\
(0.1) \\
{[0.094]}\end{array}$ & $\begin{array}{c}0.117 \\
(0.1) \\
{[0.091]}\end{array}$ & $\begin{array}{c}0.110 \\
(0.1) \\
{[0.082]}\end{array}$ & $\begin{array}{c}0.099 \\
(0.1) \\
{[0.122]}\end{array}$ \\
\hline Leverage & $\begin{array}{c}0.169 \\
(0.1) \\
{[0.157]}\end{array}$ & $\begin{array}{c}0.209 \\
(0.2) \\
{[0.172]}\end{array}$ & $\begin{array}{c}0.217 \\
(0.2) \\
{[0.173]}\end{array}$ & $\begin{array}{c}0.188 \\
(0.1) \\
{[0.180]}\end{array}$ \\
\hline Assets (millions) & $\begin{array}{c}5,377.72 \\
(563.3) \\
{[11,953.69]}\end{array}$ & $\begin{array}{c}7,175.55 \\
(1,529.1) \\
{[13,545.77]}\end{array}$ & $\begin{array}{c}6,418.75 \\
(1,242.2) \\
{[13,039.51]}\end{array}$ & $\begin{array}{c}3,525.10 \\
(327.7) \\
{[9,243.48]}\end{array}$ \\
\hline Sales (millions) & $\begin{array}{c}3,124.70 \\
(663.1) \\
{[6,233.29]}\end{array}$ & $\begin{array}{c}4,452.52 \\
(1,172.8) \\
{[7,728.11]}\end{array}$ & $\begin{array}{c}4,255.22 \\
(1,187.0) \\
{[7,610.72]}\end{array}$ & $\begin{array}{c}1,569.64 \\
(318.8) \\
{[3,902.00]}\end{array}$ \\
\hline Capex/assets & $\begin{array}{c}0.070 \\
(0.1) \\
{[0.054]}\end{array}$ & $\begin{array}{c}0.063 \\
(0.1) \\
{[0.048]}\end{array}$ & $\begin{array}{c}0.062 \\
(0.1) \\
{[0.048]}\end{array}$ & $\begin{array}{c}0.063 \\
(0.0) \\
{[0.058]}\end{array}$ \\
\hline Q & $\begin{array}{c}0.972 \\
(0.8) \\
{[0.760]}\end{array}$ & $\begin{array}{c}1.023 \\
(0.8) \\
{[0.884]}\end{array}$ & $\begin{array}{c}0.868 \\
{[0.8)} \\
{[0.576]}\end{array}$ & $\begin{array}{c}1.029 \\
(0.8) \\
{[0.949]}\end{array}$ \\
\hline Industry- Adjusted Q & $\begin{array}{c}0.082 \\
(0.0) \\
{[0.561]}\end{array}$ & $\begin{array}{c}0.098 \\
(-0.0) \\
{[0.699]}\end{array}$ & $\begin{array}{c}-0.029 \\
(-0.0) \\
{[0.489]}\end{array}$ & $\begin{array}{c}0.129 \\
(-0.0) \\
{[0.763]}\end{array}$ \\
\hline $\mathrm{N}$ & 1480 & 1884 & 1136 & 8265 \\
\hline
\end{tabular}


Table 1. Panel C. Establishment-level summary statistics for establishments owned by either ESOP firms or firms in the matched group. All variables are winsorized at the $1 \%$. Wages per employee is normalized to $\$ 2006$. Means are reported with median in parenthesis and standard deviations in brackets.

\begin{tabular}{|c|c|c|c|c|}
\hline & $\begin{array}{l}\text { Firms which later adopt } \\
\text { ESOPs }\end{array}$ & $\begin{array}{l}\text { Firms with } \\
\text { ESOPs }\end{array}$ & $\begin{array}{l}\text { Firms with } \\
\text { ESOPg5 }\end{array}$ & $\begin{array}{l}\text { Matched } \\
\text { Firms }\end{array}$ \\
\hline $\begin{array}{l}\text { Annual payroll } \\
\text { (thousands) }\end{array}$ & $\begin{array}{c}2,490.32 \\
(371.6) \\
{[6,807.09]}\end{array}$ & $\begin{array}{c}2,479.67 \\
(321.3) \\
{[6,783.98]}\end{array}$ & $\begin{array}{c}2,220.18 \\
(279.4) \\
{[6,407.07]}\end{array}$ & $\begin{array}{c}2,112.14 \\
(298.4) \\
{[6,087.46]}\end{array}$ \\
\hline Number of Employees & $\begin{array}{c}58.406 \\
(12.0) \\
{[136.42]}\end{array}$ & $\begin{array}{c}52.416 \\
(9.0) \\
{[130.07]}\end{array}$ & $\begin{array}{c}48.049 \\
(8.0) \\
{[126.05]}\end{array}$ & $\begin{array}{c}47.362 \\
(10.0) \\
{[117.93]}\end{array}$ \\
\hline $\begin{array}{l}\text { Wages per employee } \\
\text { (thousands) }\end{array}$ & $\begin{array}{c}40.522 \\
(33.9) \\
{[30.79]}\end{array}$ & $\begin{array}{c}51.893 \\
(41.1) \\
{[42.11]}\end{array}$ & $\begin{array}{c}52.981 \\
(38.1) \\
{[45.66]}\end{array}$ & $\begin{array}{c}39.693 \\
(31.5) \\
{[30.43]}\end{array}$ \\
\hline $\mathrm{N}$ & 206,433 & 364,820 & 232,664 & 671,504 \\
\hline
\end{tabular}


Table 2. Time series of log wages per employee and unexplained wages per employee. Panel A reports average log wages per employee (in thousands). Panel B reports average unexplained wages. Unexplained wages is the residual from the following regression: log wages per employee $=a_{0}+a_{1}$ state-year mean wages $+a_{2}$ industry-year mean wages $+\varepsilon$. State-year mean wages is the log mean wage per employee in the state of location of the establishment and matched by year. Industry-year mean wage is the mean log wage per employee matched to the establishment's industry and by year. For the ESOP samples, relative year represents the year relative to when the ESOP was initiated (year 0 ). The matched sample is created at the time the ESOP is initiated and then the matched firms are followed over time. Thus, for the matched sample, the relative year represents the year relative to when the firm was matched to an ESOP firm initiating an ESOP (year 0.)

Panel A: log wages per employee (in thousands)

\begin{tabular}{|c|c|c|c|}
\hline Relative Year & Small ESOP only & Large ESOP only & Matched Firm \\
\hline-2 & 3.462 & 3.521 & 3.410 \\
\hline-1 & 3.203 & 2.910 & 2.928 \\
\hline 0 & 3.448 & 3.564 & 3.211 \\
\hline 1 & 3.597 & 3.669 & 3.406 \\
\hline 2 & 3.604 & 3.773 & 3.409 \\
\hline \multicolumn{4}{|c|}{ Panel B: unexplained wages } \\
\hline-2 & 0.020 & -0.010 & -0.025 \\
\hline-1 & 0.010 & -0.020 & -0.019 \\
\hline 0 & 0.045 & 0.030 & -0.014 \\
\hline 1 & 0.090 & 0.044 & -0.016 \\
\hline 2 & 0.055 & 0.026 & -0.025 \\
\hline
\end{tabular}


Table 3. Wage changes around ESOP initiation. The dependant variable is log wages per employee. ESOP is a dummy variable which takes the value of 1 if the firm has an ESOP. ESOPg5 is a dummy variable which takes a value of 1 if the firm has an ESOP and this ESOP controls at least 5\% of the firm's outstanding common stock at any given time. All regressions include plant and year fixed effects, however, the coefficients for these additional regression variables are not reported to conserve space. Establishment age and sales are log-transformed. Sales is normalized to $\$ 2006$. The sample used is columns 1, 2, 3, and 5 includes both ESOP firms and the matched sample. Columns 4 and 6 use just the sample of firms which have an ESOP at some point (these columns exclude the matched sample.) Coefficients are reported with standard errors in parentheses. "**, "**", and "***" reflect statistical significant at the $10 \%, 5 \%$ and $1 \%$ respectively.

\begin{tabular}{|c|c|c|c|c|c|c|}
\hline & 1 & 2 & 3 & 4 & 5 & 6 \\
\hline ESOP & $\begin{array}{l}0.163 \\
(0.003) \\
* * *\end{array}$ & $\begin{array}{l}0.062 \\
(0.003) \\
* * *\end{array}$ & $\begin{array}{l}0.061 \\
(0.003) \\
* * *\end{array}$ & $\begin{array}{l}0.122 \\
(0.004) \\
* * *\end{array}$ & $\begin{array}{l}0.061 \\
(0.031) \\
* *\end{array}$ & $\begin{array}{l}0.122 \\
(0.033) \\
* * *\end{array}$ \\
\hline ESOPg5 & $\begin{array}{l}-0.023 \\
(0.004) \\
* * *\end{array}$ & $\begin{array}{l}-0.079 \\
(0.003) \\
* * *\end{array}$ & $\begin{array}{l}-0.077 \\
(0.004) \\
* * *\end{array}$ & $\begin{array}{l}-0.089 \\
(0.004) \\
* * *\end{array}$ & $\begin{array}{l}-0.077 \\
(0.043) \\
*\end{array}$ & $\begin{array}{l}-0.081 \\
(0.041) \\
* *\end{array}$ \\
\hline State-year mean wages & & $\begin{array}{l}0.610 \\
(0.005) \\
* * *\end{array}$ & $\begin{array}{l}0.608 \\
(0.005) \\
* * *\end{array}$ & $\begin{array}{l}0.651 \\
(0.008) \\
* * *\end{array}$ & $\begin{array}{l}0.608 \\
(0.115) \\
* * *\end{array}$ & $\begin{array}{l}0.651 \\
(0.066) \\
* * *\end{array}$ \\
\hline Industry- year mean wages & & $\begin{array}{l}0.368 \\
(0.004) \\
* * *\end{array}$ & $\begin{array}{l}0.368 \\
(0.004) \\
* * *\end{array}$ & $\begin{array}{l}0.299 \\
(0.007) \\
* * *\end{array}$ & $\begin{array}{l}0.368 \\
(0.110) \\
* * *\end{array}$ & $\begin{array}{l}0.299 \\
(0.057) \\
* * *\end{array}$ \\
\hline Establishment age & & & $\begin{array}{l}0.008 \\
(0.002) \\
* * *\end{array}$ & $\begin{array}{l}-0.014 \\
(0.004)\end{array}$ & $\begin{array}{l}0.008 \\
(0.015)\end{array}$ & $\begin{array}{l}-0.014 \\
(0.024)\end{array}$ \\
\hline Sales & & & $\begin{array}{l}0.000 \\
(0.001)\end{array}$ & $\begin{array}{l}-0.049 \\
(0.003) \\
* * *\end{array}$ & $\begin{array}{l}0.000 \\
(0.013)\end{array}$ & $\begin{array}{l}-0.049 \\
(0.025)\end{array}$ \\
\hline Leverage & & & $\begin{array}{l}-0.025 \\
(0.007) \\
* * *\end{array}$ & $\begin{array}{l}0.004 \\
(0.010)\end{array}$ & $\begin{array}{l}-0.025 \\
(0.045)\end{array}$ & $\begin{array}{l}0.004 \\
(0.071)\end{array}$ \\
\hline $\begin{array}{l}\text { Clustered standard errors at the } \\
\text { firm level }\end{array}$ & No & No & No & No & Yes & Yes \\
\hline $\mathrm{N}$ & $1,023,258$ & $1,023,258$ & $1,023,258$ & 417,706 & $1,023,258$ & 417,706 \\
\hline R-squared & 0.826 & 0.847 & 0.847 & 0.860 & 0.493 & 0.450 \\
\hline
\end{tabular}


Table 4. $\mathbf{Q}$ and accounting profits around ESOP initiation. The dependant variable in columns 1-6 is industry adjusted $\mathrm{Q}$, windorized at $1 \%$. $Q_{\text {it }}$ is fiscal year-end market value of equity plus market value of preferred stock plus total liabilities divided by total assets. Industry adjust Q by subtracting the median Q matched by industry (3-digit SIC code) and year. The dependant variable in columns 7-8 is industry-adjusted operating income/total assets. ESOP is a dummy variable which takes the value of 1 if the firm has an ESOP. ESOPg5 is a dummy variable which takes a value of 1 if the firm has an ESOP and this ESOP controls at least 5\% of the firm's outstanding common stock at any given time. All regressions include firm and year fixed effects and the following variables: log total assets and log sales. Both variables are normalized to $2006 \$$. However the coefficients for these control variables are not reported to conserve space. The sample used is columns 1 to 3 is the full sample of ESOP firms and a control sample of non-ESOP firms matched by 1) wages; 2) wage changes; and 3) size. The sample used in columns 4-8 the full sample of ESOP firms and a control sample of non-ESOP firms matched by 1) industry adjusted Q; and 2) size. Coefficients are reported with standard errors in parentheses. "*", "**", and "***" reflect statistical significant at the $10 \%, 5 \%$ and $1 \%$ respectively.

\begin{tabular}{|c|c|c|c|c|c|c|c|c|}
\hline & 1 & 2 & 3 & 4 & 5 & 6 & 7 & 8 \\
\hline ESOP & $\begin{array}{l}0.074 \\
(0.025) \\
* * *\end{array}$ & $\begin{array}{l}0.174 \\
(0.036) \\
* * *\end{array}$ & & $\begin{array}{l}0.163 \\
(0.038) \\
* * *\end{array}$ & $\begin{array}{l}0.135 \\
(0.038) \\
* * *\end{array}$ & $\begin{array}{l}0.150 \\
(0.038) \\
* * *\end{array}$ & $\begin{array}{l}0.0113 \\
(0.004) \\
* * *\end{array}$ & $\begin{array}{l}0.012 \\
(0.005) \\
* * *\end{array}$ \\
\hline ESOPg5 & & $\begin{array}{l}-0.175 \\
(0.044) \\
* * *\end{array}$ & $\begin{array}{l}-0.019 \\
(0.031)\end{array}$ & $\begin{array}{l}-0.157 \\
(0.046) \\
* * *\end{array}$ & $\begin{array}{l}-0.132 \\
(0.046) \\
* * *\end{array}$ & $\begin{array}{l}-0.128 \\
(0.046) \\
* * * *\end{array}$ & $\begin{array}{l}-0.014 \\
(0.005) \\
* * *\end{array}$ & $\begin{array}{l}-0.016 \\
(0.006) \\
* * *\end{array}$ \\
\hline Log assets & & & & $\begin{array}{l}-0.151 \\
(0.018) \\
* * *\end{array}$ & $\begin{array}{l}-0.656 \\
(0.055) \\
* * *\end{array}$ & & & \\
\hline Log assets squared & & & & & $\begin{array}{l}0.043 \\
(0.004) \\
* * *\end{array}$ & & & \\
\hline Log sales & & & & & & $\begin{array}{l}-0.269 \\
(0.028) \\
* * *\end{array}$ & & \\
\hline Log sales squared & & & & & & $\begin{array}{l}0.024 \\
(0.003) \\
* * *\end{array}$ & & \\
\hline R\&D / Sales & & & & $\begin{array}{l}0.230 \\
(0.068) \\
* * *\end{array}$ & $\begin{array}{l}0.216 \\
(0.067) \\
* * *\end{array}$ & $\begin{array}{l}0.177 \\
(0.068) \\
* * *\end{array}$ & & $\begin{array}{l}-0.126 \\
(0.009) \\
* * *\end{array}$ \\
\hline CapEx /Assets & & & & $\begin{array}{l}0.951 \\
(0.160) \\
* * *\end{array}$ & $\begin{array}{l}1.015 \\
(0.159) \\
* * *\end{array}$ & $\begin{array}{l}1.004 \\
(0.160) \\
* * *\end{array}$ & & $\begin{array}{l}-0.009 \\
(0.021)\end{array}$ \\
\hline Log Firm Age & & & & $\begin{array}{l}-0.104 \\
(0.024) \\
* * *\end{array}$ & $\begin{array}{l}-0.060 \\
(0.024) \\
* * *\end{array}$ & $\begin{array}{l}-0.112 \\
(0.024) \\
* * *\end{array}$ & $\begin{array}{l}-0.001 \\
(0.003)\end{array}$ & $\begin{array}{l}-0.002 \\
(0.003)\end{array}$ \\
\hline Sigma & & & & $\begin{array}{l}-3.394 \\
(0.598) \\
* * *\end{array}$ & $\begin{array}{l}-3.799 \\
(0.595) \\
* * *\end{array}$ & $\begin{array}{l}-2.474 \\
(0.594) \\
* * *\end{array}$ & & \\
\hline SigmaDum & & & & $\begin{array}{l}0.091 \\
(0.033) \\
* * *\end{array}$ & $\begin{array}{l}0.111 \\
(0.033) \\
* * *\end{array}$ & $\begin{array}{c}0.049 \\
(0.033)\end{array}$ & & \\
\hline $\mathrm{N}$ & 9524 & 9524 & 9524 & 7,665 & 7,665 & 7,661 & 8,725 & 7,968 \\
\hline $\mathrm{R}$-squared & 0.552 & 0.553 & 0.552 & 0.466 & 0.473 & 0.468 & 0.589 & 0.596 \\
\hline
\end{tabular}


Table 5. Wage changes around ESOP initiation by eHHI with ESOPcc, CCindex and TO. The dependant variable is log wages per employee. ESOP is a dummy variable which takes the value of 1 if the firm has an ESOP. ESOPg5 is a dummy variable which takes a value of 1 if the firm has an ESOP and this ESOP controls at least $5 \%$ of the firm's outstanding common stock at any given time. ESOPcc is a dummy variable which takes a value of 1 if a firm has a large ESOP and when implementing this large ESOP, the firm was in the bottom $1 / 2$ of the sample by both assets and age. CCindex takes a value of 0 if the firm does not have a large ESOP. For firms with large ESOPs, CCindex reflect the relative ranking of cash constraints where a high value of CCindex implies a cash constrained firm. TO is a dummy variable which takes a value of 0 if the firm does not have an ESOP. TO takes a value of 1 if the firm has an ESOP and this ESOP was implemented under takeover pressure. All regressions include establishment and year fixed effects, establishment age, state year mean wages, industry year mean wages, log sales and leverage, however, the coefficients for these additional regression variables are not reported to conserve space. Establishment age and sales are log-transformed. Sales is normalized to $\$ 2006$. The sample used is columns $1-3$ is the full sample of ESOP firms and the matched control sample of non-ESOP firms. The sample used in column 4 is eHHI high. eHHI high includes all plants located in industries with employee Herfindahl index values above the sample median. The sample used in column 5 is eHHI low. eHHI low includes all plants located in industries with employee Herfindahl index values below the sample median. Coefficients are reported with standard errors in parentheses. "*", "**", and "***" reflect statistical significant at the $10 \%, 5 \%$ and $1 \%$ respectively.

\begin{tabular}{|c|c|c|c|c|c|}
\hline & 1 & 2 & 3 & 4 & 5 \\
\hline Sample & All & All & All & eHHI high & eHHI low \\
\hline ESOP & $\begin{array}{l}0.061 \\
(0.003) * * *\end{array}$ & & $\begin{array}{l}0.067 \\
(0.003) \\
* * *\end{array}$ & $\begin{array}{l}-0.004 \\
(0.005)\end{array}$ & $\begin{array}{l}0.070 \\
(0.005) \\
* * *\end{array}$ \\
\hline ESOPg5 & $\begin{array}{l}-0.070 \\
(0.004) * * *\end{array}$ & $\begin{array}{l}-0.017 \\
(0.003) * * *\end{array}$ & $\begin{array}{l}-0.020 \\
(0.004) \\
* * *\end{array}$ & $\begin{array}{l}0.008 \\
(0.006)\end{array}$ & $\begin{array}{l}-0.076 \\
(0.007) \\
* * *\end{array}$ \\
\hline ESOPcc & $\begin{array}{l}-0.123 \\
(0.009) * * *\end{array}$ & $\begin{array}{l}-0.123 \\
(0.009)^{* * *}\end{array}$ & & & \\
\hline CCindex & & & $\begin{array}{l}-0.077 \\
(0.004) \\
* * *\end{array}$ & $\begin{array}{l}-0.036 \\
(0.005) \\
* * *\end{array}$ & $\begin{array}{l}-0.038 \\
(0.006) \\
* * *\end{array}$ \\
\hline TO & & & $\begin{array}{l}-0.068 \\
(0.005) \\
* * *\end{array}$ & $\begin{array}{l}0.027 \\
(0.006) \\
* * *\end{array}$ & $\begin{array}{l}-0.064 \\
(0.010) \\
* * *\end{array}$ \\
\hline $\mathrm{N}$ & $1,023,258$ & $1,023,258$ & $1.023,258$ & 531,944 & 491,314 \\
\hline R-squared & 0.847 & 0.847 & 0.847 & 0.879 & 0.847 \\
\hline
\end{tabular}


Table 6. Wage changes around ESOP initiation by eHHI with BCS and leverage. The dependant variable is log wages per employee. ESOP is a dummy variable which takes the value of 1 if the firm has an ESOP. ESOPg5 is a dummy variable which takes a value of 1 if the firm has an ESOP and this ESOP controls at least $5 \%$ of the firm's outstanding common stock at any given time. All regressions include establishment and year fixed effects, establishment age, state year mean wages, industry year mean wages, log sales and leverage, however, the coefficients for these additional regression variables are not reported to conserve space. Establishment age and sales are log-transformed. Sales is normalized to $\$ 2006$. The sample used is column 1 is the full sample of ESOP firms and the matched control sample of non-ESOP firms. The sample used in columns 2-4 is eHHI high. eHHI high includes all plants located in industries with employee Herfindahl index values above the sample median. Coefficients are reported with standard errors in parentheses. "*", "**", and "***" reflect statistical significant at the $10 \%, 5 \%$ and $1 \%$ respectively.

\begin{tabular}{|c|c|c|c|c|}
\hline & 1 & 2 & 3 & 4 \\
\hline Sample & All & eHHi high & eHHi high & eHHi high \\
\hline ESOP & $\begin{array}{l}0.061 \\
(0.003) \\
* * *\end{array}$ & $\begin{array}{l}0.026 \\
(0.015) \\
*\end{array}$ & $\begin{array}{l}-0.005 \\
(0.015)\end{array}$ & $\begin{array}{l}0.008 \\
(0.007)\end{array}$ \\
\hline ESOPg5 & $\begin{array}{l}-0.077 \\
(0.004) \\
* * *\end{array}$ & $\begin{array}{l}-0.063 \\
(0.021) \\
* * *\end{array}$ & $\begin{array}{l}-0.029 \\
(0.021)\end{array}$ & $\begin{array}{l}0.012 \\
(0.009) \\
*\end{array}$ \\
\hline BCS & $\begin{array}{l}0.003 \\
(0.002)\end{array}$ & $\begin{array}{l}-0.002 \\
(0.003)\end{array}$ & $\begin{array}{l}-0.003 \\
(0.003)\end{array}$ & \\
\hline ESOP*BCS & & $\begin{array}{l}-0.027 \\
(0.015) \\
*\end{array}$ & $\begin{array}{l}-0.027 \\
(0.015) \\
*\end{array}$ & \\
\hline ESOPg5* BCS & & $\begin{array}{l}0.048 \\
(0.021) \\
* *\end{array}$ & $\begin{array}{l}0.104 \\
(0.021) \\
* * *\end{array}$ & \\
\hline Yeardif & & & $\begin{array}{l}0.006 \\
(0.001) \\
* * *\end{array}$ & \\
\hline Yeardifg5 & & & $\begin{array}{l}-0.018 \\
(0.001) \\
* * *\end{array}$ & \\
\hline Leverage & & & & $\begin{array}{l}0.033 \\
(0.010) \\
* * *\end{array}$ \\
\hline $\begin{array}{l}\text { Leverage * } \\
\text { ESOP }\end{array}$ & & & & $\begin{array}{l}-0.038 \\
(0.029)\end{array}$ \\
\hline $\begin{array}{l}\text { Leverage * } \\
\text { ESOPg5 }\end{array}$ & & & & $\begin{array}{l}-0.095 \\
(0.031) \\
* * *\end{array}$ \\
\hline R-squared & 0.847 & 0.879 & 0.879 & 0.879 \\
\hline $\mathrm{N}$ & $1,023,258$ & 531,944 & 531,944 & 531,944 \\
\hline
\end{tabular}


Table 7. $\mathbf{Q}$ around ESOP initiation. The dependant variable is industry adjusted $Q$, windorized at $1 \%$. $\mathrm{Q}_{\mathrm{it}}$ is fiscal year-end market value of equity plus market value of preferred stock plus total liabilities divided by total assets. We follow Bebchuk and Cohen (2005) and industry adjust $Q$ by subtracting the median Q matched by industry (3-digit SIC code) and year. ESOP is a dummy variable which takes the value of 1 if the firm has an ESOP. ESOPg5 is a dummy variable which takes a value of 1 if the firm has an ESOP and this ESOP controls at least 5\% of the firm's outstanding common stock at any given time. All regressions include firm and year fixed effects and the following variables: log total assets and $\log$ sales. Both variables are normalized to $2006 \$$. However the coefficients for these control variables are not reported to conserve space. The sample used in columns 1 and 2 is eHHI high. eHHI high includes all plants located in industries with employee Herfindahl index values above the sample median. The sample used in columns 3 and 4 is eHHI low. eHHI low includes all plants located in industries with employee Herfindahl index values below the sample median. Coefficients are reported with standard errors in parentheses. "*", "**", and "***" reflect statistical significant at the $10 \%, 5 \%$ and $1 \%$ respectively.

\begin{tabular}{lllll}
\hline & 1 & 2 & 3 & 4 \\
\hline Sample & eHHI high & eHHI high & eHHI low & eHHI low \\
ESOP & 0.260 & & 0.083 & \\
& $(0.058)$ & & $(0.043)$ & \\
& $* * *$ & & -0.018 & 0.091 \\
ESOPg5 & 0.141 & 0.376 & $(0.097)$ & $(0.089)$ \\
& $(0.104)$ & $(0.090)$ & & \\
& & $* * *$ & -0.045 & -0.045 \\
CCindex & -0.352 & -0.350 & $(0.058)$ & $(0.058)$ \\
& $(0.062)$ & $(0.062)$ & & \\
& $* * *$ & $* * *$ & 4453 & 4453 \\
N & 5071 & 5071 & 0.640 & 0.640 \\
R-squared & 0.578 & 0.576 & & \\
\hline
\end{tabular}

